\title{
Extensive sclerotic masses of florid cemento-osseous dysplasia: a case report treated surgically
}

\author{
Massas escleróticas extensivas de displasia florido cemento-ósseo: \\ um relato de caso tratado cirurgicamente
}

Sanyra Lopes Dias'; Pietry dy Tarso Inã Alves Malaquias²; Roberto Almeida de Azevedo ${ }^{3}$; Adelmir Souza Machado ${ }^{4}$.

\begin{abstract}
${ }^{1}$ Odontóloga. Mestranda do Programa de Pós-graduação Processos Interativos dos Órgãos e Sistemas, ICS - UFBA
${ }^{2}$ Residente de Cirurgia Bucomaxilofacial, Hospital Santo Antonio - Obras Sociais Irmã Dulce, HGE, UFBA

${ }^{3}$ Professor Adjunto. Faculdade de Odontologia, UFBA. Coordenador da Residência em Cirurgia Bucomaxilofacial, Hospital Santo Antonio - Obras Sociais Irmã Dulce, HGE, UFBA

${ }^{4}$ Professor Adjunto. Departamento de Biomorfologia. Programa de Pós-graduação Processos Interativos dos Órgãos e Sistemas, ICS - UFBA
\end{abstract}

\begin{abstract}
Background: Florid cement-osseous dysplasia (FCOD) is a benign bone reactive process and represents a type of fibro-osseous lesion, in which normal bone is replaced by fibrous connective tissues. The lesions are most frequently seen in middle-aged black women and show a marked tendency for bilateral and symmetric involvement. The lesions usually require no treatment, and the management of the symptomatic patient is more difficult. Case report: A 42-year old black female patient was admitted to our Service of Oral and maxillofacial Surgery in the UFBA-OSID (Salvador/BA, Brazil) complaining of painful sintomatology in her mandible associated with the use of prosthesis. Panoramic radiograph revealed multiple sclerotic masses with radiolucent borders found in the maxilla and mandible. The case was diagnosed as FCOD, based in the features seen on the radiographs and clinic examination. The patient underwent surgical removal of exposed sclerotic mass. No evidence of recurrence has been seen after 12 months postoperatively. Keywords: Fibro-osseous lesion. Florid cemento-osseous dysplasia. Oral pathology.
\end{abstract}

\section{Resumo}

Introdução: displasia cemento-ossea florida (DCOF) é um processo reativo benigno dos ossos e representa um tipo de lesão fibroóssea, em que o osso normal é substituído por tecido conjuntivo fibroso. As lesões são mais frequentes em mulheres negras de meia idade, e mostram uma forte tendência para o envolvimento bilateral e simétrico. As lesões comumente não requerem tratamento, sendo o tratamento do paciente sintomático mais desafiador. Relato de caso: Uma paciente do gênero feminino, 42 anos de idade, foi admitida no Serviço de Cirurgia Oral e Maxilofacial da UFBA-OSID (Salvador-BA/Brasil), queixando-se de sintomatologia dolorosa na mandíbula associado ao uso de prótese. Radiografia panorâmica revelou múltiplas massas escleróticas com bordas radiolúcidas encontradas na maxila e mandíbula. O caso foi diagnosticado como DCOF, com base em suas características clínicas e exames de imagem. O paciente foi submetido a remoção cirúrgica da massa esclerótica. Nenhuma evidência de recorrência foi observada em 12 meses do periodo pos operatório.

Palavras-chave: Lesão fibro-óssea. Displasia cemento-óssea florida. Patologia oral.

\section{INTRODUCTION}

Fibro-osseous lesions of the jaws include fibrous dysplasia, ossifying fibroma, and cemento-osseous dysplasia $^{1}$. Cemento-osseous dysplasias are usually classified, depending on their extent and radiographic appearances, into three main groups: periapical, florid and focal cemental dysplasias ${ }^{2,3}$.

The florid cemento-osseous dysplasia (FCOD) is more commonly seen in the jaws and occurs frequently

Correspondência / Correspondence: Sanyra Lopes Dias

Endereço: Faculdade de Odontologia, Rua Araújo Pinho, n.62, 10 andar,

Canela - Salvador, Bahia, 40110-150 Telefone: +557133360540

Email: sanyrald@hotmail.com in middle-aged black women, above of 40 years ${ }^{4,5}$ and its cause remains unknown. Such disorder is often asymptomatic, and stops growing after reaching a certain size ${ }^{6}$. In cases with painful sintomatology, it has an association with chronic osteomielitis, probably decurrrent of secondary infection 7. Clinically it is characterized by sclerotic symmetrical masses ${ }^{3-6}$, with bilateral involvement ${ }^{1,5}$ and localization to the tooth-bearing or edentulous areas $^{1}$.

Usually it exhibits as multiple radiopaque cemetum-like masses distributed the jaws which radiographically appears as dense, lobulated masses ${ }^{4}$. Histologically, 
the lesion is characterised by a cementoma- or osteoma-like appearance with a lobular shape ${ }^{6}$. The need for treatment thus seems low ${ }^{1,6}$, however, secondary infection easily results from this disease, and sequestrum formation might be seen when osteomyelitis is present as a complication, requiring treatment ${ }^{6}$.

The aim of this article is to report a case of florid cemento-osseous dysplasia located in the posterior region of the mandible and maxilla addressing the surgical management for removal of exposed sclerotic mass, beyond clinical, imaging and pathological aspects.

\section{CASE PRESENTATION}

A 42-year old black female patient was admitted to our Service of Oral and maxillofacial Surgery in the UFBA-OSID (Salvador/BA, Brazil) complaining of painful sintomatology and increased volume in the posterior region of the right mandible, precluding the use of upper and lower dental prosthesis made 15 years ago. Extra-oral examination was within normal limits. Intraoral examination revealed a partially edentulous in the mandible and maxilla. In the mandible, edematous mucosa of the alveolar ledge was seen, with the presence of the bone sequestration in the region of the right mandible (Figure 1). In the maxilla there was no increase in volume and the ledge was covered with pink mucosa of normal appearance. In the panoramic radiograph (Figure 2), multiple sclerotic masses with radiolucent borders were found in the maxilla and mandible. Under local anesthesia, the patient underwent to surgical removal of exposed sclerotic mass (Figure 3) and antibiotic therapy due to local pain and inability to use the denture in order to offer better quality of life. The specimen was sent for pathological examination ( $N$. $B / 004341 / 11)$, revealing the presence of bone sequestration with acute osteomyelitis. The case was diagnosed as FCOD, based on the features seen on the radiographs and clinic examination. Despite the proximity of the sclerotic masses with the mandibular canal, there was no report of paresthesia after surgery. No evidence of recurrence has been seen as of 12 months postoperatively (Figures 4 and 5).
Figure 1. Intraoral aspect showing exposed necrotic bone.

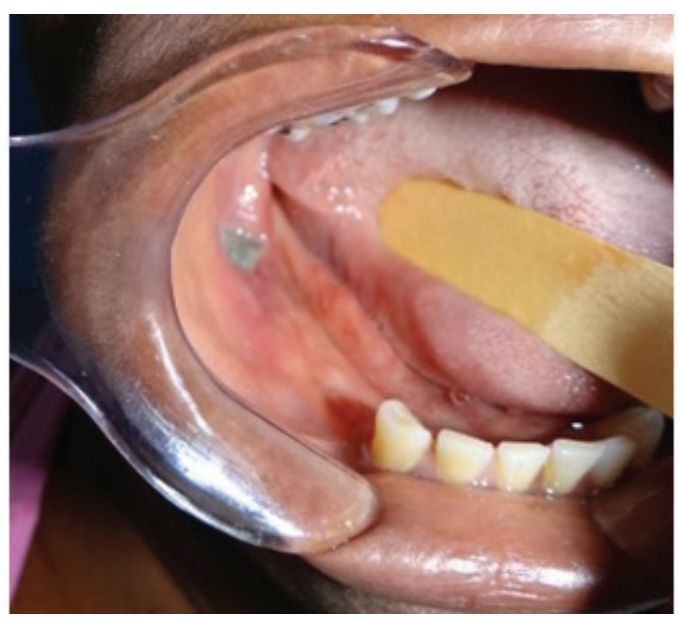

Figure 3. surgical specimen.

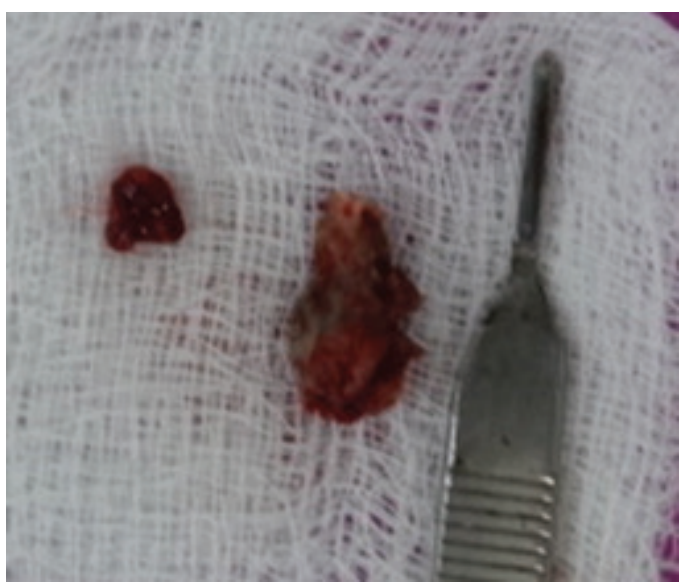

Figure 2. Pre surgical panoramic radiograph showing multiple sclerotic masses with radiolucent borders found in the maxilla and mandible.

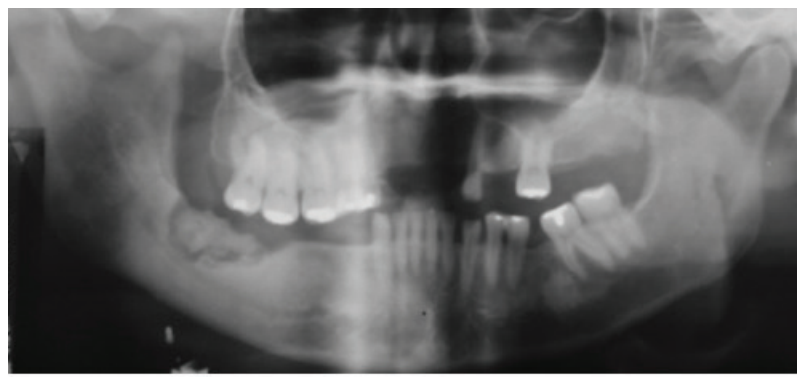

Figure 4. Pos surgical panoramic radiograph after 5 months showing in the mandibular region, an area in healing after the removal of bone sequestration.

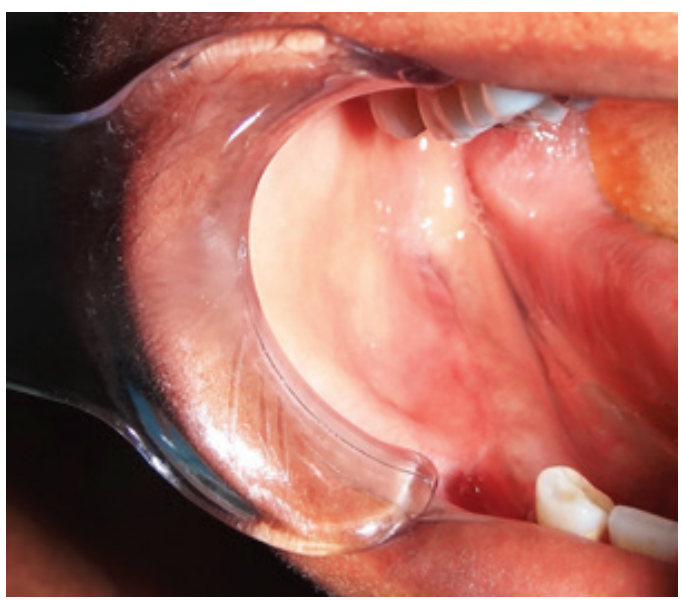


Figure 5. Postoperative aspect of the operated area showing good healing on the 12th month of follow-up.

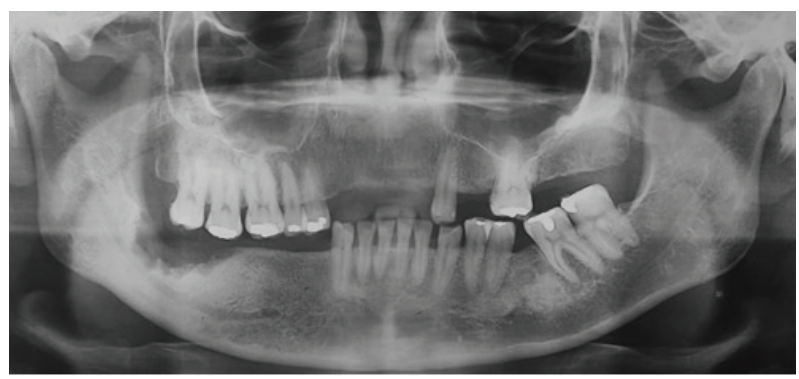

\section{DISCUSSION}

Florid cemento-osseous dysplasia (FCOD) represents a type of fibro-osseous lesion and it is usually considered a benign bone reactive process in which normal bone is replaced by poorly cellularized cementum-like materials and cellular fibrous connective tissues ${ }^{1}$.These lesions show a marked tendency for bilateral 1,5 and often symmetric involvement ${ }^{3-6}$. Moreover, the process may be totally asymptomatic and, in such cases, the lesion is detected when radiographs are taken for some other purposes 8 . In this case, we also noted the involvement of the four quadrants. However, the patient reported the presence of painful symptoms

Usually, a diagnosis of florid cemento-osseous dysplasia in the jaws is made by clinical findings, radiographic features and histology $y^{3,4,7}$. However, this dysplasia is a condition in which the diagnosis relies on clinical and radiological features alone ${ }^{3-5}$.

Radiographically, a mixed radiolucent and radiopaque appearance is a common finding and may be located in two or more quadrants. The lesions appear lobular and irregularly shaped and progress from radiolucent to radiopaque over time. Intraorally, yellowish bone-like material may be present, protruding through the oral mucosa and communicating with the oral cavity. This perforation will often result in a low-grade secondary infection, ultimately causing the patient to become symptomatic. The former and imaging features were also observed in our case leading to the diagnosis of FCOD. However, as the patient underwent to surgical removal of bone sequestration, the specimen was sent to histopathological analysis, which confirmed the diagnosis.

This kind of lesion has radiographic and histopathologic aspects found in others diseases, diffuse esclerosant osteomielitis and Paget's disease of the bone ${ }^{7}$. FCOD lesions must be differentiated from Paget's disease, Gardner's syndrome and chronic diffuse osteomyelitis ${ }^{10}$. Patients affected do not have laboratory or radiologic evidence of bone disease in other parts of the skeleton ${ }^{3,10}$, skin tumors and dental anamolies anomalies, , characteristics which differ from from Gardner's syndrome. Paget's disease is polyostotic and shows raised alkaline phosphatase levels which are not a con- sistent features of FCOD. Chronic difuse osteomyelitis is not confined to tooth bearing areas. It is a primary inflammatory condition of the mandible with cyclic episodes of unilateral pain and swelling. The affected region of the mandible exhibits a diffuse opacity with poorly defined borders ${ }^{10}$.

Symptoms such as dull pain or drainage are almost always associated with exposure of sclerotic calcified masses in the oral cavity. The affected area undergoes changes from normal vascular bone into an avascular cementum-like lesion. The lesion is usually benign and requires no treatment unless cosmetically embarassing; however, fibrous dysplasia and ossifying fibroma need surgical recontouring or total excision ${ }^{1}$. The treatment of a secondary infection of the cemento-osseous dysplasias can be difficult and complicated $d^{2,13}$ and this may occur as the result of progressive alveolar atrophy under a denture or after extraction of teeth in the area involved ${ }^{11,12}$.

Unnecessary surgical treatment of the lesions, including biopsy, since can expose the poorly vascularized bone tissue to the oral environment and incur secondary infection ${ }^{13,14}$, that is difficult to control without extensive surgical intervention ${ }^{1,3,4,14,15}$. Although there are cases of FCOD concomitant with osteomyelitis, this can only be considered as a clinical complication if the pain symptoms and fistulas displayed by the patient are associated with complications for osteomyelitis and not by dysplastic changes. The mineralized masses are highly dense, avascular and have little ability to remodel under prosthetics, predisposing to mucosal ulceration, bone exposure and training of kidnappings $\left.{ }^{12,16,1}\right)$, as noted in this patient.

Management of florid cemento-osseous dysplasia can be difficult. The disease may persist for indefinite periods of time without causing any symptoms. For the asymptomatic patient, the best management consists of regular recall examinations with prophylaxis and reinforcement of good oral hygiene care to control periodontal disease and prevent tooth loss. In the symptomatic patient is more difficult and not very satisfactory. At this stage, there is an inflammatory component to the disease and the process is basically a chronic osteomyelitis involving dysplastic bone and cementum. Antibiotics may be indicated but may not be effective ${ }^{14,18,19}$. The use of antibiotics and curettage of the affected tissue are therapeutic approaches that correspond to studies performed by Schneider et al. ${ }^{14,18,20}$. The patient of the present case was underwent surgical removal of sclerotic mass and antibiotic therapy, due to the painful symptomatology reported with bone sequestration and mucosal inflammation. The patient was followed up over the 12 months and has remained asymptomatic.

\section{REFERENCES}

1. LIN, T.M. et al. Florid cemento-osseous dysplasia (FCOD): case report. J. Dent. Sci., Taiwan, v. 5, n. 4, p. 242-245, 2010. 
2. JERJES, W. et al. Florid cemento-osseous dysplasia in a young Indian woman. A case report. Br. Dent. J., London, v. 198, n. 8, p. 477-478, 2005.

3. DAĞISTAN, S. et al. Florid cemento-osseous dysplasia: A case report. Med. Oral Patol. Oral Cir. Bucal., Valencia, v. 12, p. 348-50, 2007.

4. GUNDUZ, K. et al. Florid Cemento-Osseous Dysplasia: A Case Report. Braz. Dent. J., Ribeirão Preto, v. 20, n. 4, p. 347-350, 2009.

5. BENAZZOU, S. et al. Dysplasie cémento-osseuse floride des maxillaires. Revue de Stomatologie et de Chirurgie Maxillo-Faciale, Amsterdam, v. 112, n. 3, p. 1-3, 2011.

6. SUGIYAMA, T. et al. Florid cemento-osseous dysplasia: report of a case and review of the literature. Int. J. Oral Maxillofac. Surg., Copenhagen, v. 38, n. 5, p. 569, 2009.

7. SOUZA-JUNIOR, E.J.C. et al. Displasia cemento-óssea florida: relato de caso. Odontologia. Clín.-Cientif., Recife, v. 7, n. 4, p. 347-351, 2008.

8. GONÇALVES, M. et al. Clinical, Radiographic, Biochemical and Histological Findings of Florid Cemento-Osseous Dysplasia and Report of a Case. Braz. Dent. J., Ribeirão Preto, v. 16, n. 3, p. 247-250, 2005.

9. TONIOLI, M.D.; SCHINDLER, W.G. Treatment of a maxillary molar in a patient presenting with florid cemento-osseous dysplasia: a case report. J. Endod., Baltimore, v. 30, n. 9, p. 665-667, 2004.

10. MANGALA et al. Florid cemento-osseous dysplasia : Review and report of two cases. Indian J. Dent. Res., Ahmedabad, v. 17, n. 3, p. 131-134, 2006.
11. BEYLOUNI, I. et al. Florid cementoosseous dysplasia: report of a case documented with computed tomography and $3 D$ imaging. Oral Surg. Oral Med. Oral Pathol. Oral Radiol. Endod., St. Louis, v. 85, n. 6, p. 707-711, 1998.

12. GRASSELLI, S.; DA SILVA, C.M.; FONTANELLA, V.R.C. Displasia óssea florida. Stomatos, Canoas, v. 7, p. 55-8, 2001.

13. SARMENTO, D.J. et al. Severe florid cemento-osseous dysplasia: a case report treated conservatively and literature review. Oral Maxillofac. Surg., Heidelberg, v. 17, n. 1, p. 43-6, 2012.

14. SCHNEIDER, L.C. et al. Malignant spindle cell tumor arising in the mandible of a patient with florid osseous dysplasia. Oral Surg. Oral Med. Oral Pathol. Oral Radiol. Endod., St. Louis, v. 88, n. 1, p. 69-73, 1999.

15. DGHOUGHI, S.; ELWADY, W.; TALEB, B. La dysplasie cement-osseuse floride. Rev. Odont. Stomat., Paris, v. 39, p. 211-21, 2010.

16. SLOOTWEG, P.J. Bone diseases of the Jaws. Int. J. Dent., Cairo, $p$. $1-7,2010$.

17. HEUBERGER, B.M. et al. Dysplasie osseuse priapicale anterieure du maxillaire superieur. Rev. Mens. Suisse Odontostomatol., Bern, v. 120, p. 1007-1011, 2010.

18. SPEIGHT, P.M.; CARLOS, R. Maxillofacial fibro-osseous lesions. Curr. Diagn. Pathol., Edinburgh, v. 12, n. 1, p. 1-10, 2006.

19. MACDONALD-JANKOWSKI, D.S. Florid cemento-osseous dysplasia: a systematic review. Dentomaxillofac. Radiol., Tokyo, v. 32, n. 3, p. 141-9, 2003.

20. MACDONALD-JANKOWSKI, D.S. Fibro-osseous lesions of the face and jaws. Clin. Radiol., Edinburgh, v. 59, n. 1, p. 11-25, 2004.

Submetido em 13.11.2013;

Aceito em 20.12.2013. 